\title{
Cu-Sn Coatings Produced Using Environmentally Non-Aggressive Electrolyte Containing Sodium Tartrate
}

\author{
Priscila Santos da Silva ${ }^{a}$, Lilian Ferreira de Senna ${ }^{a}$, Dalva Cristina B. do Lago ${ }^{a}$ \\ ${ }^{a}$ Laboratório de Eletroquímica e Corrosão - LEC, Instituto de Química, Universidade do Estado do \\ Rio de Janeiro - UERJ, Rua São Francisco Xavier, 524, Pavilhão Haroldo Lisboa da Cunha, S. 427, \\ Maracanã, CEP 20550-013, Rio de Janeiro, RJ, Brazil
}

Received: December 10, 2016; Accepted: October 23, 2017

\begin{abstract}
This work proposes the production of $\mathrm{Cu}-\mathrm{Sn}$ alloy coatings with anticorrosive properties, using an environmentally non-aggressive bath. The coatings were electrodeposited on carbon steel substrate AISI 1020 using an electrolyte containing $\mathrm{CuCl}_{2}$ and $\mathrm{SnCl}_{2}$, and sodium tartrate as the complexant agent. The produced coatings were characterized by scanning electron microscopy (SEM), X-ray diffraction (XRD), inductively coupled plasma optical emission spectrometry (ICPOES) and electrochemical impedance spectroscopy (EIS). The film showing the highest corrosion resistance was obtained using $\mathrm{j}=100 \mathrm{Am}^{-2}$. This coating was composed by $95.18 \% \mathrm{~m} / \mathrm{m} \mathrm{Cu}$ and $4.83 \% \mathrm{~m} / \mathrm{m} \mathrm{Sn}$, and presented a uniform surface, without defects and small grain sizes. These characteristics probably contributed to the formation of $\mathrm{Cu}-\mathrm{Sn}$ protective film onto steel substrate from a tartrate bath.
\end{abstract}

Keywords: Coating, $\mathrm{Cu}$-Sn alloy, sodium tartrate, corrosion

\section{Introduction}

$\mathrm{Cu}-\mathrm{Sn}$ alloys coatings have a wide application in industry due to their excellent characteristics, such as low surface tension, weldability and ductility. In addition, these alloy coatings present a great corrosion resistance in comparison with those containing only copper or $\operatorname{tin}^{1}$. Generally, the corrosion resistance of the $\mathrm{Cu}-\mathrm{Sn}$ coatings increases with the Sn content in the alloy ${ }^{2}$.

$\mathrm{Cu}-\mathrm{Sn}$ alloy films are also used as decorative layers for metallic artifacts, due to their attractive appearance ${ }^{1,3}$. When the deposition conditions are chosen properly, the alloy color ranges from bright yellow to grey, directly depending on the $\mathrm{Cu}: \mathrm{Sn}$ ratio in the electrolytic bath ${ }^{2}$. However, small changes in the optimal deposition conditions may cause the formation of unattractive grey deposits ${ }^{3}$.

Electrodeposition is one of the most widely used methods to produce metallic alloys films, as the $\mathrm{Cu}-\mathrm{Sn}$ nones. This process has great economic interest because it allows less noble materials to be employed industrially as substrates, with excellent results ${ }^{4}$. The coatings obtained by this process may present, anticorrosive, mechanical, optical or electrical enhanced properties, for example ${ }^{5}$. However, the electrodeposition of metallic alloy coatings requires the simultaneous reduction of all the ions present in the bath on the electrode surface. Generally, it is not a simple task due to the high differences between the reduction potentials of the metallic ions constituting the alloy ${ }^{6}$. Even though, it is possible to make the potentials closer by using complexing agents ${ }^{4}$. Despite its high toxicity and the need for strict control of its solutions, the most widely used complexing agent in the electrodeposition of copper alloys is still the cyanide ion. Moreover, prolonged use of cyanide baths also leads to a decrease in the quality of the produced coating ${ }^{4}$. Therefore, there are several works concerning the use of alternative, environmentally-friendly electrolytic baths, that can be as efficient as cyanide ions in producing the metallic coatings ${ }^{4,6-10}$.

Among the environmentally friendly electrolytes currently used, citrates, gluconates, sulfamates, tartrates and glycinates are the most studied baths for the electrodeposition of copper alloy coatings ${ }^{7,11-13}$. These compounds are non-toxic complexing agents, easily obtained and degraded ${ }^{12,14,15}$. Previous works have shown that it is possible to obtain bright and uniform $\mathrm{Cu}-\mathrm{Zn}$ and $\mathrm{Cu}-\mathrm{Co}$ alloys coatings using environmentally favorable citrate and glycinate baths $\mathrm{s}^{4,6,10,13,16}$.

The tartrate ion is an organic additive in the electrodeposition process of different metals and alloys, as have been reported in the literature ${ }^{17,18}$. Sodium tartrate was used as an additive for the electrodeposition of $\mathrm{Cu}-\mathrm{Sn}$ alloys from an acid bath, producing levelled coatings ${ }^{19,20}$. The tartrate ion is known as a complexing agent for $\mathrm{Cu}$ (II) and $\mathrm{Sn}$ (II) ions. As a bidentate ligand, it is able to form chelates of $\mathrm{Cu}$ (II) ions in a wide $\mathrm{pH}$ region $^{21}$. It is expected that the tartrate ion form stable $\mathrm{Cu}$-Tartrate complexes, favoring the reduction of the $\mathrm{Sn}$ (II) ions and then facilitating the formation of the $\mathrm{Cu}-\mathrm{Sn}$ alloy.

Therefore, the aim of this work was to produce $\mathrm{Cu}-\mathrm{Sn}$ alloy coatings on carbon steel substrates, using an environmentally non-aggressive electrolytic bath based on sodium tartrate as the complexing agent. The coatings were produced using direct current and were characterized by scanning electron microscopy (SEM), X-ray diffraction (XRD), inductively coupled plasma optical emission spectrometry (ICPOES) 
and electrochemical impedance spectroscopy (EIS), to verify the effect of the applied current density on the anticorrosive properties of the produced coating/substrate systems.

\section{Experimental Procedures}

\subsection{Cathodic polarization curve}

The cathodic polarization curve of the steel substrate was obtained in a solution containing $\mathrm{CuCl}_{2} .2 \mathrm{H}_{2} \mathrm{O} 0.20$ mol L-1, $\mathrm{SnCl}_{2} .2 \mathrm{H}_{2} \mathrm{O} 0.02 \mathrm{~mol} \mathrm{~L}^{-1}$ and sodium tartrate 0.50 mol L-1 $(\mathrm{pH}=5.65)$, under constant stirring conditions $(300 \mathrm{rpm})$. The curve was performed using a potentiostat AUTOLAB PGSTAT302N, in a potential range between the open circuit potential $\left(\mathrm{E}_{\mathrm{OCP}}\right)$ and $-2.00 \mathrm{~V}(\mathrm{SCE})$, and a scanning speed $1 \mathrm{mV} \mathrm{s}^{-1}$.

A three-electrode electrochemical cell was used, consisting of an AISI 1020 carbon steel disk as the working electrode (exposed area $=4.9 \mathrm{~cm}^{2}$ ), the saturated calomel electrode $\left(\mathrm{Hg} / \mathrm{Hg}_{2} \mathrm{Cl}_{2}, \mathrm{SCE}\right)$ as the reference electrode, and a Pt spiral as counter electrode. The steel electrode was first sanded with emery paper (100 to 600 mesh), polished with alumina grade no. 2, washed with deionized water and alcohol and finally dried, before being immersed in the solution. The Pt spiral was immersed in $20 \% \mathrm{v} / \mathrm{v} \mathrm{HNO}_{3}$ solution for 1 minute, immediately before being used in the experiment, to remove any oxide layer that could be present.

\subsection{Electrodeposition experiments}

The electrodeposition experiments were carried out in duplicate series, using the same potentiostat/galvanostat and the electrochemical cell earlier described in topic 2.1, as well as the same cleaning procedures for both the work and the counter electrodes used. Based on the polarization curves, seven values of current density $\left(5 \mathrm{~A} \mathrm{~m}^{-2}, 10 \mathrm{~A} \mathrm{~m}^{-2}, 20 \mathrm{~A} \mathrm{~m}^{-2}\right.$, $50 \mathrm{~A} \mathrm{~m}^{-2}, 80 \mathrm{~A} \mathrm{~m}^{-2}, 100 \mathrm{~A} \mathrm{~m}^{-2}$ e $200 \mathrm{~A} \mathrm{~m}^{-2}$ ) were selected to produce the $\mathrm{Cu}-\mathrm{Sn}$ alloys on a steel substrate, under the same temperature $\left(25^{\circ} \mathrm{C}\right)$ and stirring speed $(300 \mathrm{rpm})$ conditions mentioned in the section 2.1. Each electrodeposition time was calculated, based on the Faraday's law, to produce a $10 \mathrm{mg}$ coating.

The produced layers were dissolved in $20 \% \mathrm{v} / \mathrm{v} \mathrm{HNO}_{3}$, and the alloy composition was determined by inductively coupled plasma optical emission spectrometry plasma (ICPOES), using an equipment Thermo SCIENTIFIC iCAP 6000 SERIES. These results and the theoretical mass obtained from the Faraday's law were used to calculate the cathodic current efficiency $\left(E_{f}\right)$ value for each deposition time ${ }^{6,10,22}$.

The content of each metal in the coatings was calculated as the $\% \boldsymbol{m} / \boldsymbol{m} \boldsymbol{C u}$ and $\% \boldsymbol{m} / \boldsymbol{m} \boldsymbol{S n}$, using Equations (1) and (2), respectively.

$$
\% m / m C u=\frac{m_{C u}}{m_{C u}+m_{S n}} \times 100
$$

$$
\% m / m S n=\frac{m_{S n}}{m_{C u}+m_{S n}} \times 100
$$

Based on the electrodeposition experiments, partial polarization curves were obtained by calculating the effective currents densities used for copper and tin deposition $\left(\mathrm{j}_{\mathrm{Cu}}\right.$ and $\mathrm{j}_{\mathrm{Sn}}$, respectively) from the element contents in the alloy coating and the current efficiency. In each case, the partial currents were associated with the corresponding potential response of the total applied current density.

\subsection{Coatings characterization}

\subsubsection{Morphological analysis}

Scanning electron microscopy (SEM) was performed using a JEOL JSM G510 LV microscope to evaluate the effect of the current density on the surface morphology of the coatings. The samples were cleaned with alcohol, dried and adapted to the stub using a conductive tape. The analysis was carried out in high vacuum and in the secondary electron mode, using voltage of $20 \mathrm{kV}$.

\subsubsection{Microstructural characterization}

Microstructural analysis of the $\mathrm{Cu}-\mathrm{Sn}$ coating was performed by X-ray diffraction (XRD) using a diffractometer Rigaku Ultima IV and $\mathrm{Cu}-\mathrm{K} \alpha$ radiation $(\lambda=1.5406 \AA)$, at $40 \mathrm{kV}$. The $2 \theta$ ranged from $10^{\circ}$ to $100^{\circ}$, at a scanning rate of $0.020^{\circ} \mathrm{s}^{-1}$. The identification of the microstructural phases in the deposited sample was carried out by using the software Materials Date JADE 5 XRD pattern processing. The more prominent diffractogram lines from the $\mathrm{Cu}-\mathrm{Sn}$ alloy deposit were fitted by a Gaussian equation (using Microcal Origin ${ }^{\circledR}$, release 8.0 ) to determine the $2 \theta$ values used to calculate the $d(\mathrm{hkl})$ parameters of the diffraction lines. The same fitting was used to determinate the full width at half maximum (FWHM) and the height of the most prominent line. As the FWHM of the X-ray diffraction line is related to the apparent size of the particle ${ }^{23}$, this parameter was used to evaluate the size of the crystallites using Equation (3):

$$
d_{p}=\frac{k \lambda}{\beta \cos \theta}
$$

where $d_{p}$ is the crystallite size, $\mathrm{k}$ is a constant related to the type of the crystal structure, $\lambda$ is the wavelength of the incident radiation (nm), and $\beta$ is the $\mathrm{FWHM}^{23}$.

\subsubsection{Corrosion experiments}

Electrochemical impedance spectroscopy (EIS) experiments were used to evaluate the anticorrosive ability of the $\mathrm{Cu}$-Sn coatings produced on steel substrate under the conditions described in section 2.2. The experiments were carried out at $25^{\circ} \mathrm{C}$, in $\mathrm{NaCl} 0.5 \mathrm{~mol} \mathrm{~L}^{-1}(\mathrm{pH}=7.06)$, using 
a three-electrode cell, in which the working electrodes were the coating/substrate systems produced using each current density, the counter electrode was a platinum spiral, and the reference electrode was a saturated calomel electrode (SCE).

The EIS evaluations were performed in duplicate, at the open circuit potentials of the samples, after potential stabilization (approximately $1 \mathrm{~h}$ ), in a frequency range of $10^{5}$ to $10^{-3} \mathrm{~Hz}$ and amplitude of $10 \mathrm{mV}$. A potentiostat/ galvanostat AUTOLAB PGSTAT 302N was used to perform these experiments.

The EIS data were fitted using the NOVA 1.10 software (Metrohm Autolab). The values of the double layer electrical capacitance $\left(\mathrm{C}_{\mathrm{DCE}}\right)$ were calculated from the constant phase element (CPE) using Equation (4):

$$
\mathrm{C}_{\mathrm{DCE}}=(\mathrm{CPE})^{\frac{1}{\mathrm{~N}}} \times \mathrm{R}_{\mathrm{tc}}^{\left(\frac{1}{\mathrm{~N}^{-}}-1\right)}
$$

\section{Results and Discussion}

\subsection{Cathodic polarization curves}

Figure 1 shows the polarization curve obtained for the carbon steel electrode using the solution containing $\mathrm{Cu}$ (II) and Sn (II) ions, as well as sodium tartrate as the complexant agent. This curve was performed to select the current density values (j) for the electrodeposition tests.

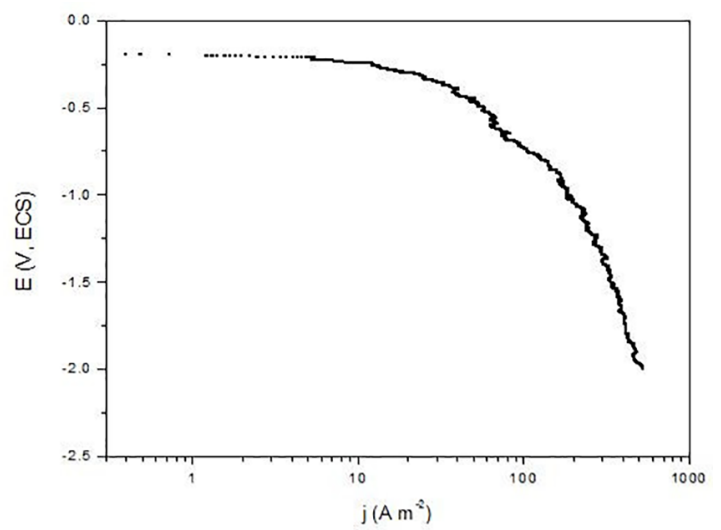

Figure 1. Cathodic polarization curve of carbon steel substrate obtained from the solution containing $\mathrm{Cu}$ (II) and $\mathrm{Sn}$ (II) ions, as well as sodium tartrate as the complexant agent.

As $\mathrm{Cu}$ (II) is the noblest ion in the bath, it is expected that lower current density values favor the copper deposition ${ }^{6,10}$, ${ }^{24}$. On the other hand, higher current density values would be useful to obtain tin-rich coatings. However, it is also important to point out that at higher cathodic current density region (very negative potentials) the hydrogen evolution reaction (HER) should prevail to the reduction of Sn (II) ions. Thus, analyzing all the polarization curve in Figure 1, seven current density (j) values have been chosen $\left(5 \mathrm{~A} \mathrm{~m}^{-2}\right.$, $10 \mathrm{~A} \mathrm{~m}^{-2}, 20 \mathrm{~A} \mathrm{~m}^{-2}, 50 \mathrm{~A} \mathrm{~m}^{-2}, 80 \mathrm{~A} \mathrm{~m}^{-2}, 100 \mathrm{~A} \mathrm{~m}^{-2}$ and $200 \mathrm{~A}$ $\mathrm{m}^{-2}$ ) to produce the metallic coatings in a wide range of copper and tin contents.

\subsection{Electrodeposition of $\mathrm{Cu}$-Sn coatings}

The $\mathrm{Cu}-\mathrm{Sn}$ coatings were produced in duplicate, by galvanostatic electrodeposition on carbon steel using the selected current density (j) values. Although Silva et al. ${ }^{4}$ have shown that adherent $\mathrm{Cu}-\mathrm{Zn}$ coatings could be produced from a citrate bath even at small values of cathodic current densities $\left(<10 \mathrm{~A} \mathrm{~m}^{-2}\right)$, the $\mathrm{Cu}-\mathrm{Sn}$ coatings produced from the tartrate bath used in the present work were not adherent to the substrate when $\mathrm{j}=5 \mathrm{~A} \mathrm{~m}^{-2}$ and $\mathrm{j}=10 \mathrm{~A} \mathrm{~m}^{-2}$ were used. Therefore, the results shown here are related only to the adherent coatings, obtained at $20 \mathrm{~A} \mathrm{~m}^{-2}, 50 \mathrm{~A} \mathrm{~m}^{-2}, 80 \mathrm{~A} \mathrm{~m}^{-2}$, $100 \mathrm{~A} \mathrm{~m}^{-2}$ and $200 \mathrm{~A} \mathrm{~m}^{-2}$.

Figure 2 shows the average values obtained for the cathodic current efficiency $\left(\mathrm{E}_{\mathrm{f}}\right)$ in each applied current density. The $\mathrm{E}_{\mathrm{f}}$ values were relatively high, with the highest value $(84 \%)$ obtained for the coating produced at $\mathrm{j}=80 \mathrm{~A}$ $\mathrm{m}^{-2}$. However, none of the used current densities values reached $\mathrm{E}_{\mathrm{f}}=100 \%$ value. These results indicate that other parallel reactions may have occurred, which could compete with the main reduction reactions of the metallic ions. The hydrogen evolution reaction (HER) was the most likely parallel reaction that consumed part of the applied current density, thereby preventing that $\mathrm{E}_{\mathrm{f}}=100 \%$ be obtained in the deposition process.

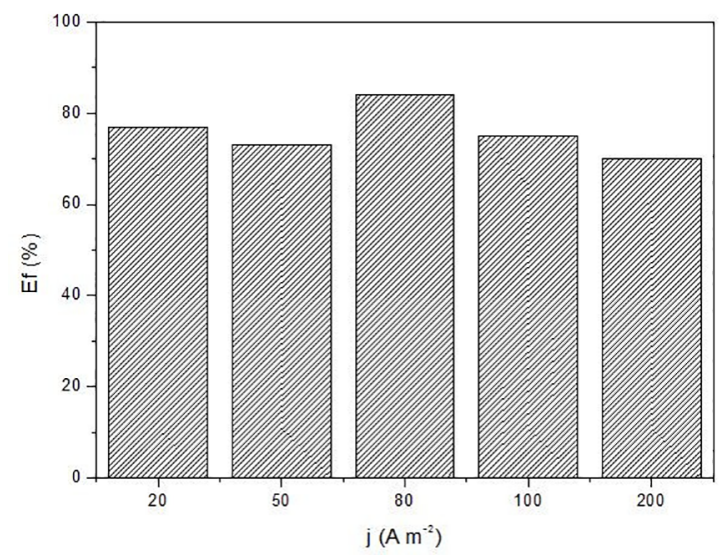

Figure 2. Average values of cathodic current efficiency $\left(E_{f}\right)$ obtained from the electrodeposition experiments.

Table 1 shows the average results for the content of the elements $\mathrm{Cu}(\% \mathbf{m} / \boldsymbol{m} \boldsymbol{C u})$ and $\mathrm{Sn}(\% \mathbf{m} / \boldsymbol{m} \boldsymbol{S n})$ obtained for each $\mathrm{j}$ value used. In all cases, the values of $\% \mathbf{m} / \boldsymbol{m} \boldsymbol{C u}$ were always higher than the $\% \mathbf{m} / \boldsymbol{m} \boldsymbol{S n}$.

Higher values of $\% \mathbf{m} / \boldsymbol{m} \boldsymbol{C u}$ in the deposited alloy were expected because it was used an electrolyte with $\mathrm{Cu}: \mathrm{Sn}=$ 10:1. Even though, it was expected that the $\% \mathbf{m} / \boldsymbol{m} \boldsymbol{S n}$ in 
Table 1. Average contents of metals in the $\mathrm{Cu}-\mathrm{Sn}$ coatings.

\begin{tabular}{|c|c|c|}
\hline Samples & $\begin{array}{c}\text { Content of } \mathrm{Cu} \\
(\% \mathrm{~m} / \mathrm{m})\end{array}$ & $\begin{array}{c}\text { Content of Sn } \\
(\% \mathrm{~m} / \mathrm{m})\end{array}$ \\
\hline $\mathbf{j}=\mathbf{2 0} \mathrm{A} \mathrm{m}^{-2}$ & 100.00 & - \\
\hline $\mathbf{j}=\mathbf{5 0} \mathrm{A} \mathrm{m}^{-2}$ & 96.44 & 3.56 \\
\hline $\mathbf{j}=\mathbf{8 0} \mathrm{A} \mathrm{m}^{-2}$ & 94.29 & 5.18 \\
\hline $\mathbf{j}=100 \mathrm{~A} \mathrm{~m}^{-2}$ & 95.18 & 4.83 \\
\hline $\mathbf{j}=200 \mathrm{~A} \mathrm{~m}^{-2}$ & 98.30 & 1.71 \\
\hline
\end{tabular}

the alloy could vary in a wider range, with the different $j$ values used. It is important to mention, however, that under the $\mathrm{pH}$ conditions used in these experiments $(\mathrm{pH}=5.65)$ the prevalent specie is the tartrate anion $\left(\mathrm{L}^{2-}\right)$. Therefore, the stability constants for $\mathrm{Cu}$-tartrate $\left(\mathrm{CuL}_{2}^{2-}\right)$ and Sn-tartrate $\left(S n L_{2}^{2-}\right)$ complexes under this condition are, respectively, $1.00 \times 10^{4}$ and $3.02 \times 10^{1125}$, suggesting that the reduction of both metallic ions, mainly Sn (II) ions, would be more difficult in a bath containing sodium tartrate than in a simple aqueous bath.

$\mathrm{Cu}-\mathrm{Sn}$ alloy coating containing around $4-10 \% \mathrm{~m} / \mathrm{m}$ of tin present anticorrosive properties and may also be used as decorative parts ${ }^{26}$. The chemical composition of coatings produced in the present work (Table 1) was near that of the commercial bronze $(95 \% \mathrm{~m} / \mathrm{m} \mathrm{Cu}$ and $5 \% \mathrm{~m} / \mathrm{m} \mathrm{Sn})$ for most of the experiments, except for the conditions $\mathrm{j}=20 \mathrm{~A} \mathrm{~m}^{-2}$ and $\mathrm{j}=200 \mathrm{~A} \mathrm{~m}^{-2}$. In the condition $\mathrm{j}=20 \mathrm{~A} \mathrm{~m}^{-2}$, only copper was deposited, while at $\mathrm{j}=200 \mathrm{~A} \mathrm{~m}^{-2}$, the negative potential value likely favored the HER instead of the Sn (II) ions reduction. Therefore, the applied current density affected the chemical composition of the $\mathrm{Cu}-\mathrm{Sn}$ alloy deposited on steel.

Based on the current efficiency data and on the chemical composition of the alloy, it was possible to calculate, for each $\mathrm{j}$ value, the effective contribution of the deposition process of each metallic ion as their partial current density $\left(\mathrm{j}_{\mathrm{Cu}}, \mathrm{j}_{\mathrm{Sn}}\right)$. As the HER was considered as main parallel reaction in the process, the partial current density for the hydrogen reduction $\left(\mathrm{j}_{\mathrm{H}}\right)$ was also calculated. $\mathrm{j}_{\mathrm{H}}$ was obtained as the difference between the total applied current density $\left(\mathrm{j}_{\text {total }}\right)$ and $\mathrm{j}_{\mathrm{Cu}}+\mathrm{j}_{\mathrm{Sn}}$. These results are shown in Figure 3.

It is possible to note that the $\mathrm{j}_{\mathrm{Cu}}$ curve is closer to the $j_{\text {total }}$ curve, which shows that the $\mathrm{j}$ values used to the electrodeposition of the alloys have been mostly used for the reduction of $\mathrm{Cu}$ (II) ions, as seen in Table 1. It can also be observed that the $j_{H}$ curve is closer to $j_{\text {total }}$ than the $j_{S n}$ curve, confirming that the $\mathrm{Sn}$ (II) ions reduction reaction was disfavored when compared to HER, especially at $\mathrm{j}=200 \mathrm{~A}$ $\mathrm{m}^{-2}$. The high value $\left(3.02 \times 10^{11}\right)$ of the stability constant for the Sn-tartrate $\left(S n L_{2}^{2-}\right)$ complex could have contributed for this result.

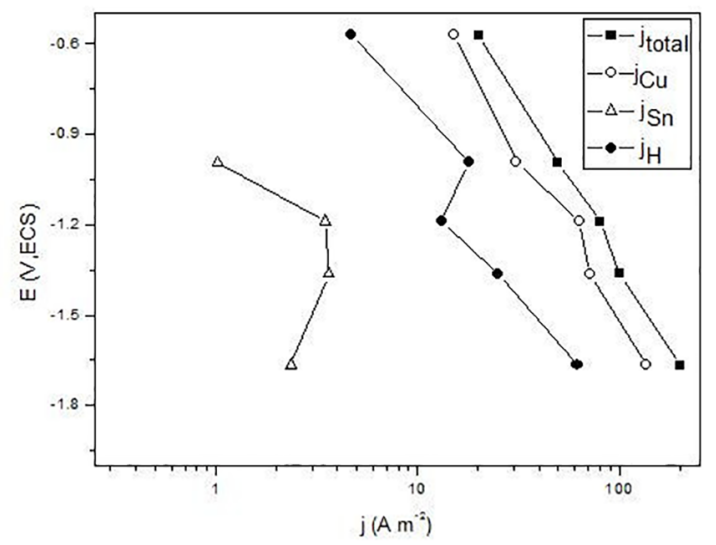

Figure 3. Partial current densities obtained in the deposition process for the metals $\mathrm{Cu}$ and $\mathrm{Sn}$ and also for the hydrogen reduction process.

\subsection{Morphological evaluation by scanning electron microscopy (SEM)}

Figure 4 shows the morphologies obtained for the $\mathrm{Cu}-\mathrm{Sn}$ alloys surfaces produced under the conditions described in the present work.

All the produced coatings were uniform, covering all the surface of the carbon steel substrate, presenting well-distributed grains for all over the surface and no visible defects. The morphology of $\mathrm{Cu}-\mathrm{Sn}$ alloys in the form of spherical grains is well reported in literature ${ }^{1,27,28}$.Other surface morphologies are also reported for $\mathrm{Cu}-\mathrm{Sn}$ alloys, such as needles ${ }^{29}$ and the dendritic morphology ${ }^{30}$. This latter morphology is usually associated with a coating in which the copper ions reduction was favored, decreasing the reduction of tin ions. Moreover, these films lacks adhesion. In the present work, no coatings presented the dendritic morphology. Coarse spherical grains were obtained for the coatings produced at $\mathrm{j}=20 \mathrm{~A} \mathrm{~m}^{-2}$ and $\mathrm{j}=50 \mathrm{~A} \mathrm{~m}^{-2}$ (Figures $4 \mathrm{~A}$ and $4 \mathrm{~B}$, respectively), while those produced using higher current density values tended to became more refined, decreasing the grain size. Coatings containing around $5 \% \mathrm{~m} / \mathrm{m}$ Sn presented a more compact morphology (Figures 4B, 4C and 4D), while loose layer scan be observed on the surface of thoses amples containing no or few amounts of tin (Figures 4A and 4E). This result shows that the variable $\mathrm{j}$ affected both the composition and the morphology of the coatings. A higher surface uniformity and smaller grain sizes were observed in the coating produced using $\mathrm{j}=100 \mathrm{~A} \mathrm{~m}^{-2}$ (Figure 4D).

\subsection{Anticorrosive evaluation of the coatings}

Figure 5 shows the Nyquist diagrams for the $\mathrm{Cu}-\mathrm{Sn}$ coating/steel substrate systems in $\mathrm{NaCl} 0.5 \mathrm{~mol} \mathrm{~L}^{-1}$. The Nyquist diagram for the naked carbon steel substrate in the 

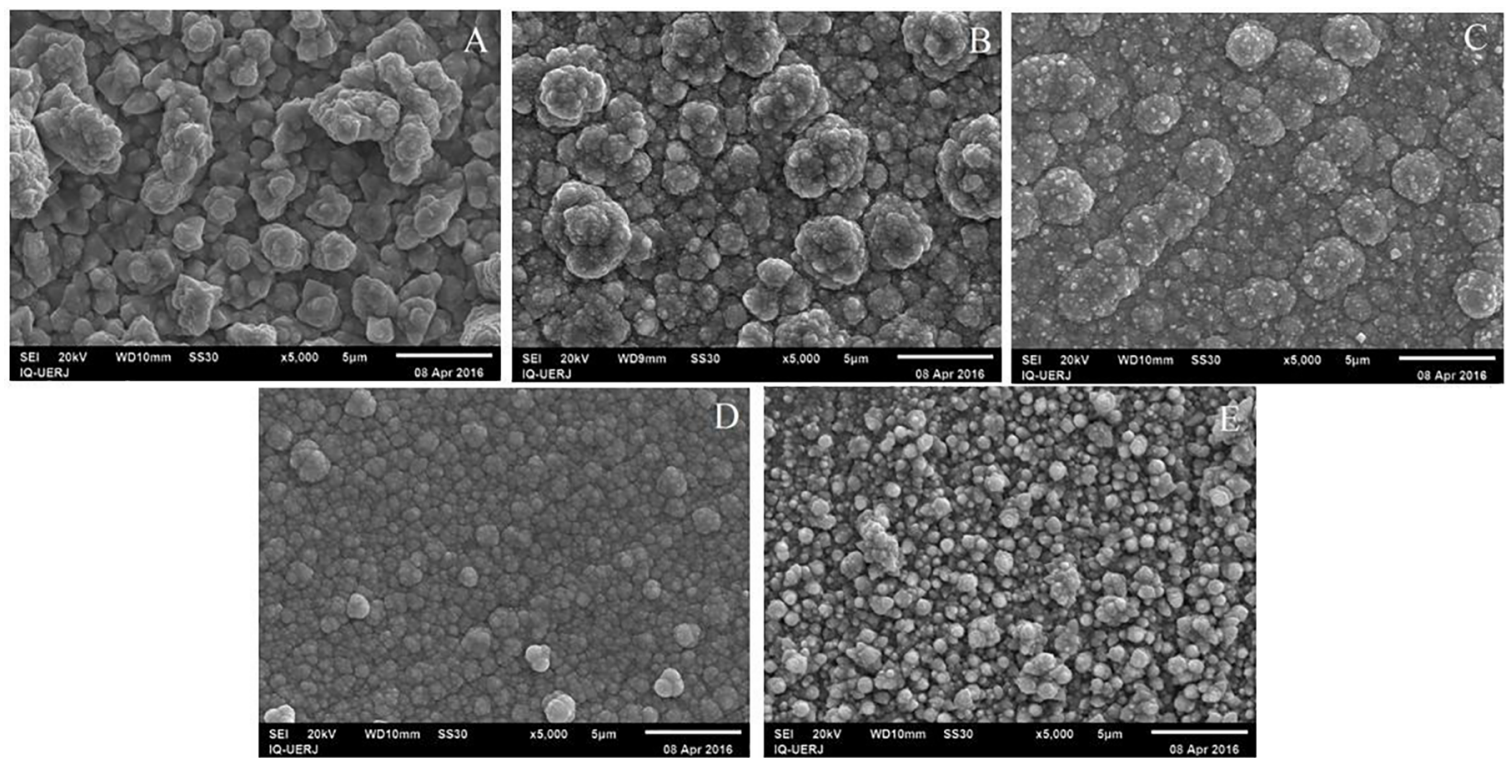

Figure 4. Surface morphology of the $\mathrm{Cu}-\mathrm{Sn}$ coatings produced using the selected current densities: $(A) j=20 \mathrm{~A} \mathrm{~m}^{-2} ;(B) j=50 \mathrm{~A} \mathrm{~m}{ }^{-2}$; (C) $\mathrm{j}=80 \mathrm{~A} \mathrm{~m}^{-2} ;(D) \mathrm{j}=100 \mathrm{~A} \mathrm{~m}^{-2}$; (E) $\mathrm{j}=200 \mathrm{~A} \mathrm{~m}^{-2}$.

same electrolyte is also shown, as comparison. The diameters of the capacitive loops in the Nyquist diagram indicate a higher coating resistance to charge transfer. In Figure 5, it can be observed that only the coating produced using $\mathrm{j}=$ $100 \mathrm{Am}^{-2}$ presented a capacitive loop diameter higher than that obtained for the bare carbon steel substrate. This result suggests that only the film produced using this current density value could be considered as a protective coating, decreasing the corrosion of the substrate. On the other hand, the coatings produced using the other $j$ values did not show satisfactory anticorrosive resistance, mainly those produced at $\mathrm{j}=20 \mathrm{~A} \mathrm{~m}^{-2}$ and $\mathrm{j}=200 \mathrm{~A} \mathrm{~m}^{-2}$.

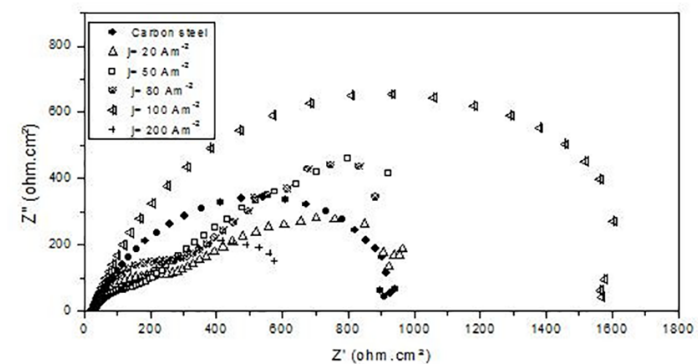

Figure 5. Nyquist diagrams for the $\mathrm{Cu}-\mathrm{Sn}$ coatings and the carbon steel after 1 hour of stabilization in $\mathrm{NaCl} 0.5 \mathrm{~mol} \mathrm{~L}^{-1}$

The results of EIS can also be analyzed using equivalent electrical circuit models, where the values of charge transfer resistance $\left(\mathrm{R}_{\mathrm{c}}\right)$ and capacitance of the double electric layer $\left(\mathrm{C}_{\mathrm{DCE}}\right)$ are obtained by simulating the electrochemical data ${ }^{31}$. Figure 6A illustrates the circuit used to simulate the EIS data obtained for the bare carbon steel substrate, where $\mathrm{R}_{\mathrm{s}}$ is the electrolyte resistance $\mathrm{R}_{\mathrm{ct}}$ is the charge transfer resistance, and CPE represents the constant phase element associated with the capacitance of the electric double layer. The EIS data for the $\mathrm{Cu}$-Sn coatings were simulated using a different equivalent circuit model, shown in Figure 6B, due to the presence of a film (the coating) on the mild steel substrate surface. In this case, $\mathrm{R}_{\mathrm{f}}$ and $\mathrm{CPE}_{\mathrm{f}}$ refer to the resistance and constant phase element of the film, respectively. The fitting was considered appropriate for an error value lower than $1 \%{ }^{32}$.

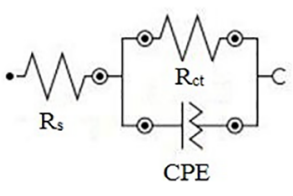

(A)

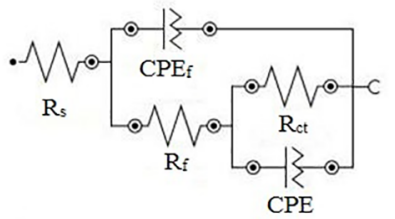

(B)
Figure 6. Equivalent circuit models used to simulate the EIS data of (A) the bare carbon steel substrate; (B) the $\mathrm{Cu}-\mathrm{Sn}$ coatings.

The $\mathrm{R}_{\mathrm{ct}}$ and $\mathrm{C}_{\mathrm{DCE}}$ values obtained after the simulation of the EIS data of all tests are presented in Table 2. An increase in the $\mathrm{R}_{\mathrm{ct}}$ and a decrease in $\mathrm{C}_{\mathrm{DCE}}$ values can be related to coatings presenting anticorrosive characteristics ${ }^{1,2}$. As the capacitance of the double electric layer is related to the tendency of substrate to undergo oxidation, small $\mathrm{C}_{\mathrm{DCE}}$ values indicate that the films showed high corrosion resistance. The $\mathrm{C}_{\mathrm{DCE}}$ and $\mathrm{C}_{\mathrm{DCEf}}$ values, also shown in Table 2, were calculated using Equation 4 (section 2.3.3).

Comparing to the results obtained for the bare carbon steel substrate, there is an increase in the $\mathrm{R}_{\mathrm{ct}}$ values and a decrease in the $\mathrm{C}_{\mathrm{DCE}}$ values, when the coated samples were analyzed. The exceptions are noted for the coatings produced at $\mathrm{j}=20 \mathrm{~A} \mathrm{~m}^{-2}(100 \% \mathrm{~m} / \mathrm{m} \mathrm{Cu})$ and $\mathrm{j}=200 \mathrm{~A} \mathrm{~m}^{-2}(98.30 \%$ 
Table 2. $\mathrm{R}_{\mathrm{ct}}$ and CDCE values obtained from the simulation of the EIS data for carbon steel and $\mathrm{Cu}-\mathrm{Sn}$ coatings in $\mathrm{NaCl} 0.5 \mathrm{~mol} \mathrm{~L}^{-1}$.

\begin{tabular}{|c|c|c|c|c|c|c|c|}
\hline Samples & $\begin{array}{l}\mathbf{R}_{\mathrm{s}} \\
(\mathbf{\Omega})\end{array}$ & $\underset{\left(\Omega \mathrm{cm}^{2}\right)}{R_{\mathrm{ct}}}$ & $\begin{array}{c}\mathrm{C}_{\mathrm{DCE}} \\
\left(\mathrm{F} \mathrm{cm}^{-2}\right)\end{array}$ & $\mathbf{N}$ & $\begin{array}{c}R_{\mathrm{f}} \\
\left(\Omega \mathrm{cm}^{2}\right)\end{array}$ & $\begin{array}{c}\mathrm{C}_{\text {DCEf }} \\
\left(\mathrm{F} \mathbf{~ c m}^{-2}\right)\end{array}$ & $\mathbf{N}_{\mathrm{f}}$ \\
\hline $\begin{array}{c}\text { Carbon steel } \\
\text { substrate }\end{array}$ & 6.31 & 911.4 & $3.24 \times 10^{-4}$ & 0.746 & - & - & - \\
\hline $\mathbf{j}=\mathbf{2 0} \mathrm{A} \mathrm{m}^{-2}$ & 4.81 & 901.6 & $8.71 \times 10^{-4}$ & 0.612 & 242.60 & $1.45 \times 10^{-4}$ & 0.797 \\
\hline $\mathbf{j}=\mathbf{5 0} \mathrm{A} \mathrm{m}^{-2}$ & 6.26 & 1107.4 & $2.65 \times 10^{-4}$ & 0.682 & 197.47 & $1.74 \times 10^{-4}$ & 0.731 \\
\hline $\mathbf{j}=80 \mathrm{~A} \mathrm{~m}^{-2}$ & 6.18 & 1095.7 & $3.16 \times 10^{-4}$ & 0.715 & 207.12 & $9.22 \times 10^{-4}$ & 0.743 \\
\hline $\mathbf{j}=100 \mathrm{~A} \mathrm{~m}^{-2}$ & 6.12 & 1543.5 & $2.12 \times 10^{-4}$ & 0.704 & 211.68 & $4.98 \times 10^{-4}$ & 0.862 \\
\hline $\mathbf{j}=\mathbf{2 0 0} \mathrm{A} \mathrm{m}^{-2}$ & 5.64 & 622.3 & $3.80 \times 10^{-2}$ & 0.669 & 131.81 & $2.27 \times 10^{-3}$ & 0.734 \\
\hline
\end{tabular}

$\mathrm{m} / \mathrm{m} \mathrm{Cu}$ and $1.71 \% \mathrm{~m} / \mathrm{m} \mathrm{Sn})$, where smaller $\mathrm{R}_{\mathrm{ct}}$ values and larger values of $\mathrm{C}_{\mathrm{DCE}}$, compared to the bare steel substrate, were verified. This result indicates that the films formed under these conditions were not resistant to corrosion in the aggressive medium used. Figures $4 \mathrm{~A}$ and $4 \mathrm{E}$ have shown that these experiments produced coatings with loose morphologies, which could have contributed for the EIS results obtained. On the other hand, the coatings produced using $\mathrm{j}=50 \mathrm{~A} \mathrm{~m}^{-2}$, $\mathrm{j}=80 \mathrm{~A} \mathrm{~m}^{-2}$ and $\mathrm{j}=100 \mathrm{~A} \mathrm{~m}^{-2}$ presented $\% \mathrm{~m} / \mathrm{m} \mathrm{Sn}$ around 5 $\% \mathrm{~m} / \mathrm{m}$ and a more compact morphology, as seen in Figures 4B, 4C and 4D, respectively. Therefore, it is possible to verify that, as the applied $\mathrm{j}$ values have influenced on the Sn content and on the morphology of the coatings, this parameter also affected their anticorrosive properties.

Confirming the observation of the Nyquist diagram, the coating produced using $\mathrm{j}=100 \mathrm{~A} \mathrm{~m}^{-2}(95.18 \% \mathrm{~m} / \mathrm{m}$ $\mathrm{Cu}$ and $4.83 \% \mathrm{~m} / \mathrm{m} \mathrm{Sn}$ ) presented the best anticorrosive performance, showing the highest $\mathrm{R}_{\mathrm{ct}}$ value and the smallest value of $\mathrm{C}_{\mathrm{DCE}}$. This coating also presented a refined and compact morphology, with small grain size and no defects (Figure 4D). These characteristics likely contributed to the performance of this film as a protective coating. Therefore, this coating was selected to be microstructurally characterized and to have its anticorrosive performance evaluated for long periods of immersion in the corrosive environment.

\subsection{Characterization of the Coating Produced at $j=100 \mathrm{~A} \mathrm{~m}^{-2}$}

\subsubsection{Microstructural evaluation}

The microstructure of the selected $\mathrm{Cu}-\mathrm{Sn}$ coating was evaluated by XRD technique and the diffractogram obtained for this coating is shown in Figure 7. It is possible to observe well-defined diffraction lines related to the coating and to the steel substrate. However, this line presented low intensity. This may be due probably to the fact the film produced is thin $\left(1.89 \times 10^{-4} \mathrm{~cm}\right)$ and also by the small diameter of the grain $(15.93 \mathrm{~nm}$, calculated based on the most intense diffraction line $2 \theta=43.5^{\circ}$ ).

Table 3 shows the experimental $2 \theta$ and $d$ (hkl) values obtained for the main diffraction lines observed for the selected coating. The corresponding $d(\mathrm{hkl})$ values obtained from the

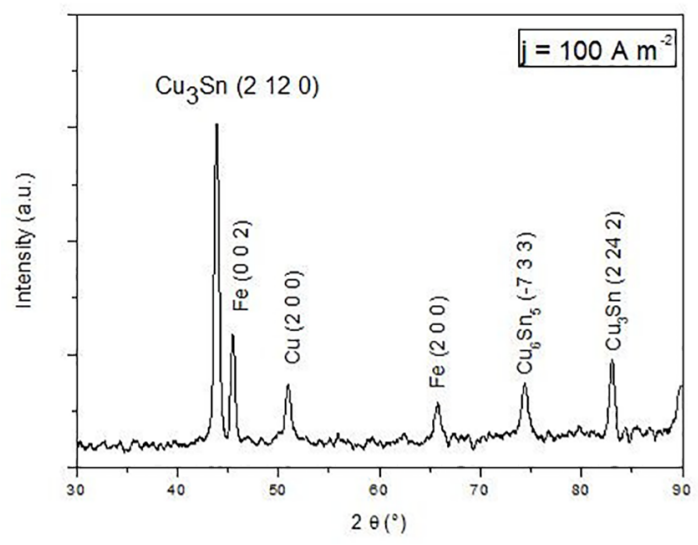

Figure 7. $\mathrm{XRD}$ analysis for $\mathrm{Cu}-\mathrm{Sn}$ coating produced using $\mathrm{j}=$ $100 \mathrm{~A} \mathrm{~m}^{-2}$.

database (Materials Data JADE 5 XRD pattern processing) are also shown, for comparison. The most intense diffraction line $\left(2 \theta=43.5^{\circ}\right.$ (PDF $\left.\left.n^{\circ} .01-1240\right)\right)$ is associated with the intermetallic phase $\mathrm{Cu}_{3} \mathrm{Sn}$. Low intensity peaks are related to the substrate, $\mathrm{Fe}\left(2 \theta=46.03^{\circ}\left(\mathrm{PDF} \mathrm{n}^{\circ}\right.\right.$. 34-0529) and $2 \theta$ $=65.02\left(\mathrm{PDF} \mathrm{n}^{\circ}\right.$. 06-0696)), to a copper segregated phase $\left(2 \theta=50.4^{\circ}\left(\mathrm{PDF} \mathrm{N}^{\circ} .04-0836\right)\right)$, and also to the intermetallic phase $\mathrm{Cu}_{6} \mathrm{Sn}_{5}\left(2 \theta=74.4^{\circ}\right.$ (PDF $\left.n^{\circ} .45-1488\right)$ ).

Barbano et al..$^{33}$ evaluated the electrodeposition of $\mathrm{Cu}-$ Sn alloys in bath containing EDTA and observed that the produced $\mathrm{Cu}-\mathrm{Sn}$ layers presented mainly the $\mathrm{Cu}_{3} \mathrm{Sn}$ and $\mathrm{Cu}_{6} \mathrm{Sn}_{5}$ phases, with no $\mathrm{Cu}$ or $\mathrm{Sn}$ segregated phases. The intermetallic $\mathrm{Cu}_{3} \mathrm{Sn}$ and $\mathrm{Cu}_{6} \mathrm{Sn}_{5}$ phases were also detected by and Low and $\mathrm{Walsh}^{34}$, when investigating the electrodeposition of $\mathrm{Cu}-\mathrm{Sn}$ alloys from a methanesulfonic acid electrolyte containing perfluorinated cationic surfactant. In this case, however, segregated tin phases were also observed. $\mathrm{Cu}-$ Sn alloys coatings were produced from a bath containing sorbitol by Finazzi et al. ${ }^{8}$ and the main phases evidenced in the XRD pattern were $\mathrm{Cu}_{3} \mathrm{Sn}$ and a segregated $\mathrm{Cu}$ phase. Therefore, the microstructural phases obtained in the present work for the selected $\mathrm{Cu}$-Sn coating are in accordance with the main results presented in the literature. Although these authors have not related the presence of these phases with an increase in corrosion resistance, it can be suggested that 
Table 3. Values of $d(\mathrm{hkl})$ for the $\mathrm{Cu}-\mathrm{Sn}$ coating produced using $\mathrm{j}=100 \mathrm{~A} \mathrm{~m}^{-2}$.

\begin{tabular}{|c|c|c|c|c|c|}
\hline $2 \theta\left({ }^{\circ}\right)$ (observed) & d (hkl) (observed) & $\mathrm{d}(\mathrm{hkl})$ carbon steel & $\mathrm{d}(\mathrm{hkl}) \mathrm{Cu}_{3} \mathrm{Sn}$ & $\mathrm{d}(\mathrm{hkl}) \mathrm{Cu}_{6} \mathrm{Sn}_{5}$ & $\mathrm{~d}(\mathrm{hkl}) \mathrm{Cu}$ \\
\hline 43.8 & 2.070 & & 2.080 & & \\
\hline 45.9 & 1.977 & 1.970 & & & \\
\hline 50.7 & 1.801 & & & & 1.808 \\
\hline 65.8 & 1.419 & 1.433 & & & \\
\hline 74.4 & 1.275 & & & 1.274 & 1.278 \\
\hline 83.0 & 1.163 & 1.170 & 1.160 & & \\
\hline
\end{tabular}

the small grain size in the coating obtained in the condition of $\mathrm{j}=100 \mathrm{Am}^{-2}(15.93 \mathrm{~nm})$, contributed to the performance of this film as a protective coating ${ }^{1}$.

\subsubsection{Long-term anticorrosive evaluation}

The coating obtained using $\mathrm{j}=100 \mathrm{~A} \mathrm{~m}^{-2}$ was evaluated by EIS after being immersed in the corrosive environment for 24 hours, in order to verify its behavior as a long-term anticorrosive coating. As a comparison, Figure 8 shows the Nyquist diagram for this coating after 24 hours and 1 hour of immersion in $\mathrm{NaCl} 0.5 \mathrm{~mol} \mathrm{~L}^{-1}$. It can be seen that the diameter of the capacitive loop of the $\mathrm{Cu}-\mathrm{Sn}$ coating after 24 hours of immersion in $\mathrm{NaCl} 0.5 \mathrm{~mol} \mathrm{~L}^{-1}$ increased, when compared to the same coating evaluated after 1 hour of immersion. This result suggests that the film produced using $\mathrm{j}=100 \mathrm{~A} \mathrm{~m}^{-2}$ provided long-term corrosion resistance for carbon steel in $\mathrm{NaCl} 0.5 \mathrm{~mol} \mathrm{~L}^{-1}$.

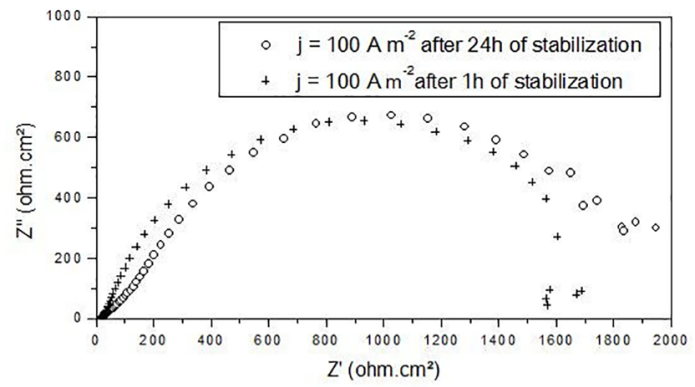

Figure 8. Nyquist diagram of the $\mathrm{Cu}-\mathrm{Sn}$ coating obtained using $\mathrm{j}=100 \mathrm{~A} \mathrm{~m}^{-2}$ after $1 \mathrm{~h}$ and $24 \mathrm{~h}$ of immersion in $\mathrm{NaCl} 0.5 \mathrm{~mol} \mathrm{~L}^{-1}$.

Table 4 shows the $\mathrm{R}_{\mathrm{ct}}$ and $\mathrm{C}_{\mathrm{DCE}}$ values obtained after the simulation of EIS data, using the circuit shown in Figure 6B, for the $\mathrm{Cu}$-Sn coating analyzed after 24 hours of immersion. The results obtained for the experiment performed with the same system, after being immersed for $1 \mathrm{~h}$ in the same corrosive medium are also presented in this table, for comparison.

It is possible to note that the coating analyzed after 24 hours of immersion in $\mathrm{NaCl} 0.5 \mathrm{~mol} \mathrm{~L}^{-1}$ showed a higher $\mathrm{R}_{\mathrm{ct}}$ value and a lower $\mathrm{C}_{\mathrm{DCE}}$ value, when compared to the results of the same coating after 1 hour of immersion, confirming the results seen in the Nyquist diagram (Figure 8). The longterm exposure ( $\sim 21$ hours) of $\mathrm{Cu}-\mathrm{Sn}$ alloy in $\mathrm{NaCl}$ solution leads to the formation of $\mathrm{SnO}_{2}$ and $\mathrm{Cu}_{2} \mathrm{O}$ on the surface of the material, as observed by Debiemme-Chouvy et al. ${ }^{35}$ using X-ray photoelectron spectroscopy (XPS). Šatović et al..$^{36}$ considered the presence of these oxides on the surface of bronze $\left(\mathrm{Cu}_{6} \mathrm{Sn}\right)$, exposed to $\mathrm{Na}_{2} \mathrm{SO}_{4} 0.015 \mathrm{~mol} \mathrm{~L}^{-1}$ solution, as the responsible for the increasing in the $\mathrm{R}_{\mathrm{ct}}$ values after 48 hours of exposure. Therefore, in the present work, the observed result can be related to the formation of metallic oxides on the coating surface, preventing its dissolution and contributing to the increase in the $\mathrm{R}_{\mathrm{ct}}$ values.

\section{Conclusions}

$\mathrm{Cu}-\mathrm{Sn}$ alloy coatings were electrodeposited on carbon steel using an electrolytic bath containing sodium tartrate. The cathodic current efficiency $\left(\mathrm{E}_{\mathrm{f}}\right)$ values, obtained for all the experiments, were higher than $70 \%$ and the coatings presented chemical composition close to that of the commercial bronze, except when the smallest $\left(j=20 \mathrm{~A} \mathrm{~m}^{-2}\right)$ and the highest $(200$ $\mathrm{A} \mathrm{m}^{-2}$ ) values of current density were used.

Uniform coatings, presenting more refined morphology and smaller grain size were obtained as the current density increased, until $\mathrm{j}=100 \mathrm{~A} \mathrm{~m}^{-2}$. The electrochemical characterization showed that the corrosion protection of the produced films increased in a similar way and the film obtained using $\mathrm{j}=100 \mathrm{~A} \mathrm{~m}^{-2}$ presented the highest corrosion resistance. The XRD analysis of this film showed, mainly,

Table 4. $R_{c t}$ and $C_{D C E}$ values obtained from the simulation of the EIS data of the $\mathrm{Cu}-\mathrm{Sn}$ coating produced using $\mathrm{j}=100 \mathrm{~A} \mathrm{~m}{ }^{-2}$, after $1 \mathrm{~h}$ and $24 \mathrm{~h}$ of immersion in $\mathrm{NaCl} 0.5 \mathrm{~mol} \mathrm{~L}^{-1}$

\begin{tabular}{|c|c|c|c|c|c|c|c|}
\hline Samples & $\begin{array}{l}\mathrm{R}_{\mathrm{s}} \\
(\mathbf{\Omega})\end{array}$ & $\begin{array}{c}R_{\mathrm{ct}} \\
\left(\Omega \mathrm{m}^{2}\right)\end{array}$ & $\begin{array}{c}\mathrm{C}_{\mathrm{DCE}} \\
\left(\mathrm{F} \mathrm{cm}^{-2}\right)\end{array}$ & $\mathbf{N}$ & $\begin{array}{c}R_{\mathrm{f}} \\
\left(\Omega \mathrm{cm}^{2}\right)\end{array}$ & $\underset{\left(\mathrm{F} \mathrm{cm}^{-2}\right)}{\mathrm{C}_{\mathrm{DCEF}}}$ & $\mathbf{N}_{\mathrm{f}}$ \\
\hline $\mathrm{j}=100 \mathrm{~A} \mathrm{~m}^{-2} 1$ hour of stabilization & 6.12 & 1543.5 & $2.12 \times 10^{-4}$ & 0.704 & 211.68 & $4.98 \times 10^{-4}$ & 0.862 \\
\hline $\mathrm{j}=100 \mathrm{~A} \mathrm{~m}^{-2} 24$ hours of stabilization & 4.70 & 1960.0 & $4.71 \times 10^{-5}$ & 0.770 & 269.50 & $7.59 \times 10^{-4}$ & 0.677 \\
\hline
\end{tabular}


the presence of $\mathrm{Cu}_{3} \mathrm{Sn}$ and $\mathrm{Cu}_{6} \mathrm{Sn}_{5}$ phases. Moreover, it presented an improved anticorrosive performance after $24 \mathrm{~h}$ of immersion in $\mathrm{NaCl}$ solution, indicating that this coating/ substrate system could be used for long-term application in aggressive environments.

\section{Acknowledgements}

The authors would like to thank the Coordination for the Improvement of Higher Level Personnel (CAPES), Rio de Janeiro Research Foundation (FAPERJ), the Brazilian National Research Council (CNPq), the State University of Rio de Janeiro (UERJ), and the Prociência Program for financial support. We would like also to thank Antônio Vitor de Castro Braga for technical support, and Isaac Mallet (LabMEV/UERJ) for the SEM analysis.

\section{References}

1. Subramanian B, Mohan S, Jayakrishnan S. Structural, microstructural and corrosion properties of brush plated copper-tin alloy coatings. Surface and Coatings Technology. 2006;201(3-4):1145-1151.

2. Sürme Y, Gürten AA, Bayol E, Ersoy E. Systematic corrosion investigation of various $\mathrm{Cu}-\mathrm{Sn}$ alloys electrodeposited on mild steel in acidic solution: dependence of alloy composition. Journal of Alloys and Compounds. 2009;485(1-2):98-103.

3. Juškènas R, Mockus Z, Kanapeckaitè S, Stalnionis G, Survila A. XRD studies of the phase composition of the electrodeposited copper-rich Cu-Sn alloys. Electrochimica Acta. 2006;52(3):928935.

4. Silva FLG, Lago DCB, D'Elia E, Senna LF. Electrodeposition of $\mathrm{Cu}-\mathrm{Zn}$ alloy coatings from citrate baths containing benzotriazole and cysteine as additives. Journal of Applied Electrochemistry. 2010;40(11):2013-2022.

5. Landolt D. Electrochemical and materials science aspects of alloy deposition. Electrochimica Acta. 1994;39(8-9):1075-1090.

6. Ferreira FBA, Silva FLG, Luna AS, Lago DCB, Senna LF. Response surface modeling and optimization to study the influence of deposition parameters on the electrodeposition of $\mathrm{Cu}-\mathrm{Zn}$ alloys in citrate medium. Journal of Applied Electrochemistry. 2007;37(4):473-481.

7. Survila A, Mockus Z, Kanapeckaitė S, Jasulaitienė V, Juškẻnas R. Codeposition of copper and tin from acid sulphate solutions containing gluconic acid. Journal of Electroanalytical Chemistry. 2010;647(2):123-127.

8. Finazzi GA, de Oliveira EM, Carlos IA. Development of a sorbitol alkaline $\mathrm{Cu}-\mathrm{Sn}$ plating bath and chemical, physical and morphological characterization of $\mathrm{Cu}-\mathrm{Sn}$ films. Surface and Coatings Technology. 2004;187(2-3):377-387.

9. Heidari G, Khoie SMM, Abrishami ME, Javanbakht M. Electrodeposition of $\mathrm{Cu}$-Sn alloys: theoretical and experimental approaches. Journal of Materials Science: Materials in Electronics. 2015;26(3):1969-1976.
10. Silva FLG, Garcia JR, Cruz VGM, Luna AS, Lago DCB, Senna LF. Response surface analysis to evaluate the influence of deposition parameters on the electrodeposition of $\mathrm{Cu}-\mathrm{Co}$ alloys in citrate medium. Journal of Applied Electrochemistry. 2008;38(12):1763-1769.

11. Guaus E, Torrent-Burgués J. Tin-zinc electrodeposition from sulphate-tartrate baths. Journal of Electroanalytical Chemistry. 2005;575(2):301-309.

12. Garcia JR, Lago DCB, Senna LF. Electrodeposition of Cobalt Rich Zn-Co alloy Coatings from Citrate Bath. Materials Research. 2014;17(4):947-957.

13. de Lima TG, Rocha BCCA, Braga AVC, Lago DCB, Luna AS, Senna LF. Response surface modeling and voltammetric evaluation of Co-rich $\mathrm{Cu}$-Co alloy coatings obtained from glycine baths. Surface and Coatings Technology. 2015;276:606-617.

14. Rashwan SM, Mohamed AE, Abdel-Wahaab SM, Kamel MM. Electrodeposition and characterization of thin layers of $\mathrm{Zn}$ Co alloys obtained from glycinate baths. Journal of Applied Electrochemistry. 2003;33(11):1035-1042.

15. Szczygieł B, Laszczyńska A, Tylus W. Influence of molybdenum on properties of $\mathrm{Zn}-\mathrm{Ni}$ and $\mathrm{Zn}-\mathrm{Co}$ alloy coatings. Surface and Coatings Technology. 2010;204(9-10):1438-1444.

16. Garcia JR, Lago DCB, Silva FLG, D'Elia E, Luna AS, Senna LF. Statistic evaluation of cysteine and allyl alcohol as additives for $\mathrm{Cu}-\mathrm{Zn}$ coatings from citrate baths. Materials Research 2013;16(2):392-403.

17. Guaus E, Torrent-Burgués J. Voltammetric study of Sn (II) reduction on a glassy-carbon electrode from sulfate-tartrate baths. Russian Journal of Electrochemistry. 2006;42(2):141146.

18. Ballesteros JC, Chainet E, Ozil P, Meas Y, Trejo G. Electrodeposition of Copper from Non-Cyanide Alkaline Solution Containing Tartrate. International Journal of Electrochemical Science. 2011;6:2632-2651.

19. Carlos IA, Bidoia ED, Pallone EMJA, Almeida MRH, Souza CAC. Effect of tartrate content on aging and deposition condition of copper-tin electrodeposits from a non-cyanide acid bath. Surface and Coatings Technology. 2002;157(1):14-18.

20. Carlos IA, Souza CAC, Pallone EMJA, Francisco RHP, Cardoso V, Lima-Neto BS. Effect of tartrate on the morphological characteristics of the copper-tin electrodeposits from a noncyanide acid bath. Journal of Applied Electrochemistry. 2000;30(8):987-994.

21. Baliukienë V, Survilienë A, Survila A. Electroreduction of $\mathrm{Cu}$ (II)-tartrate complexes in acid media. Chemija (Vilnius). 2001;12(3):216-220.

22. Trejo G, Ortega R, Meas Y, Chaînet E, Ozil P. Effect of benzylideneacetone on the electrodeposition mechanism of $\mathrm{Zn}-\mathrm{Co}$ alloy. Journal of Applied Electrochemistry. 2003;33(5):373-379.

23. Cullity BD. Elements of X-Ray Diffraction. $2^{\text {nd }}$ ed. Reading: Addison Wesley; 1978.

24. Breder H, Lago DCB, Senna LF. Efeito de aditivos nas propriedades anticorrosivas de revestimentos de liga $\mathrm{Cu} / \mathrm{Zn}$. In: Congresso Latinoamericano de Corrosão - Latincorr; 2006 May 21-26; Fortaleza, CE, Brazil. 
25. Perrin DD. Stability Constants of Metal Ion Complexes. IUPAC Chemical Data Series n ${ }^{\circ}$ 22. Oxford: Pergamon Press; 1979.

26. Mockus Z, Kanapeckaité S, Jasulaitiené V, Survila A. Electrodeposition of yellow bronze from acidic sulfate baths containing polyether laprol and micromolar additives of halides. Protection of Metals. 2006;42(5):485-490.

27. Han C, Liu Q, Ivey DG. Nucleation of Sn and Sn-Cu alloys on $\mathrm{Pt}$ during electrodeposition from $\mathrm{Sn}$-citrate and $\mathrm{Sn}-\mathrm{Cu}$-citrate solutions. Electrochimica Acta. 2009;54(12):3419-3427.

28. Zanella C, Xing S, Deflorian F. Effect of electrodeposition parameters on chemical and morphological characteristics of $\mathrm{Cu}-\mathrm{Sn}$ coatings from a methanesulfonic acid electrolyte. Surface and Coatings Technology. 2013;236:394-399.

29. Meudre C, Ricq L, Hihn JY, Moutarlier V, Monnin A, Heintz O. Adsorption of gelatin during electrodeposition of copper and tin-copper alloys from acid sulfate electrolyte. Surface and Coatings Technology. 2014;252:93-101.

30. Correia AN, Façanha MX, de Lima-Neto P. Cu-Sn coatings obtained from pyrophosphate-based electrolytes. Surface and Coatings Technology. 2007;201(16-17):7216-7221.

31. de Carvalho LA, de Andrade AR, Bueno PR. Espectroscopia de impedância eletroquímica aplicada ao estudo das reações heterogêneas em ânodos dimensionalmente estáveis. Química Nova. 2006;29(4):796-804.

32. Bayoudh S, Othmane A, Ponsonnet L, Ouada HB. Electrical detection and characterization of bacterial adhesion using electrochemical impedance spectroscopy-based flow chamber. Colloids and Surfaces A: Physicochemical and Engineering Aspects. 2008;318(1):291-300.

33. Barbano EP, de Oliveira GM, de Carvalho MF, Carlos IA. Copper-tin electrodeposition from an acid solution containing EDTA added. Surface and Coatings Technology. 2014;240:14-22.

34. Low CTJ, Walsh FC. Electrodeposition of tin, copper and tin-copper alloys from a methanesulfonic acid electrolyte containing a perfluorinated cationic surfactant. Surface and Coatings Technology. 2008;202(8):1339-1349.

35. Debiemme-Chouvy C, Ammeloot F, Sutter EMM. X-ray photoemission investigation of the corrosion film formed on a polished $\mathrm{Cu}-13 \mathrm{Sn}$ alloy in aerated $\mathrm{NaCl}$ solution. Applied Surface Science. 2001;174(1):55-61.

36. Šatović D, Žulj LV, Desnica V, Fazinić S, Martinez S. Corrosion evaluation and surface characterization of the corrosion product layer formed on $\mathrm{Cu}-6 \mathrm{Sn}$ bronze in aqueous $\mathrm{Na}_{2} \mathrm{SO}_{4}$ solution. Corrosion Science. 2009;51(8):1596-1603. 